\title{
Middle East respiratory syndrome coronavirus in pediatrics: a report of seven cases from Saudi Arabia
}

\author{
Sarah H. Alfaraj ${ }^{1,2}$, Jaffar A. Al-Tawfiq ${ }^{3,4}$, Talal A. Altuwaijri ${ }^{5}$, Ziad A. Memish $(\bowtie)^{6,7,8}$ \\ ${ }^{1}$ University of British Columbia, Vancouver, V6T 1Z4, Canada; ${ }^{2}$ Corona Center, Infectious Diseases Division, Department of Pediatric, \\ Prince Mohamed Bin Abdulaziz Hospital, Ministry of Health, Riyadh 11676, Saudi Arabia; ${ }^{3}$ Indiana University School of Medicine, \\ Indianapolis, IN 46202, USA; ${ }^{4}$ Johns Hopkins Aramco Healthcare, Dhahran 31311, Saudi Arabia; ${ }^{5}$ Department of Surgery, King Saud \\ University, Riyadh 11692, Saudi Arabia; ${ }^{6}$ College of Medicine, Alfaisal University, Riyadh 11533, Saudi Arabia; ${ }^{7}$ Infectious Diseases \\ Division, Department of Medicine, Prince Mohamed Bin Abdulaziz Hospital, Ministry of Health, Riyadh 11676, Saudi Arabia; ${ }^{8}$ Hubert \\ Department of Global Health, Rollins School of Public Health, Emory University, Atlanta, GA 30322, USA
}

(C) Higher Education Press and Springer-Verlag GmbH Germany, part of Springer Nature 2018

\begin{abstract}
Infection with Middle East respiratory syndrome coronavirus (MERS-CoV) emerged in 2012 as an important respiratory disease with high fatality rates of $40 \%-60 \%$. Despite the increased number of cases over subsequent years, the number of pediatric cases remained low. A review of studies conducted from June 2012 to April 19, 2016 reported 31 pediatric MERS-CoV cases. In this paper, we present the clinical and laboratory features of seven patients with pediatric MERS. Five patients had no underlying medical illnesses, and three patients were asymptomatic. Of the seven cases, four (57\%) patients sought medical advice within 1-7 days from the onset of symptoms. The three other patients $(43 \%)$ were asymptomatic and were in contact with patients with confirmed diagnosis of MERS-CoV. The most common presenting symptoms were fever (57\%), cough (14\%), shortness of breath (14\%), vomiting $(28 \%)$, and diarrhea $(28 \%)$. Two $(28.6 \%)$ patients had platelet counts of $<150$ $\times 10^{9} / \mathrm{L}$, and one patient had an underlying end-stage renal disease. The remaining patients presented with normal blood count, liver function, and urea and creatinine levels. The documented MERS-CoV Ct values were 32-38 for four of the seven cases. Two patients $(\mathbf{2 8 . 6 \%})$ had abnormal chest radiographic findings of bilateral infiltration. One patient $(\mathbf{1 4 . 3 \%})$ required ventilator support, and two patients $(28.6 \%)$ required oxygen supplementation. All the seven patients were discharged without complications.
\end{abstract}

Keywords Middle East respiratory syndrome coronavirus; MERS-CoV; pregnancy; pediatrics

\section{Introduction}

Middle East respiratory syndrome coronavirus (MERS$\mathrm{CoV}$ ) was initially described and detected in 2012 in a patient from the Kingdom of Saudi Arabia (KSA) [1]. Infection with this virus exhibits high fatality rates of $40 \%-60 \%$ [2-5]. The number of cases affected with MERS-CoV reached 2015, and 703 patients died of the resulting disease [6]. The hallmark of the disease is the predominance of transmission in health-care settings [2,3,7-13], where human-to-human transmission is the main route of transmission and causes the majority of cases. In community settings, the transmission of MERS-

Received June 19, 2017; accepted October 23, 2017

Correspondence: Ziad A. Memish, zmemish@yahoo.com
CoV has been believed to occur from dromedary camels to humans. Community transmissions also occur in household settings [14]. Another feature of the disease is the occurrence of few cases among children [4,15]. The first reported case in the pediatric age group involved a child from Jeddah, KSA on June 28, 2013 [16]. A recent review included 31 pediatric MERS-CoV cases within a 5-year period [17]. In a study on 2235 children with acute viral respiratory infections, none was tested positive for MERS$\mathrm{CoV}$ [18]. From 2012 to 2015 in KSA, a total of 1250 patients were reported to have MERS-CoV infection, and $3.3 \%$ of them aged less than 10 years [19]. In another analysis of 109 cases between April 23, 2014 and August $31,2015,4.2 \%$ of the patients aged less than 20 years [20]. From April 2015 to February 2016, 57363 residents (18.4/ 10 000) were suspected with and tested positive for MERS-CoV infection in KSA, and only $0.7 \%$ was tested 
positive for MERS-CoV infection [21]. In the same period, $10(0.1 \%)$ of 8032 children aged less than 14 years were positive for MERS-CoV [21]. In 2015, the case definition included a specific description of children who needed testing and those who were exposed to camels or camel products or to a confirmed or suspected MERS case and children with unexplained severe pneumonia [22]. In this paper, we present the clinical and laboratory features of seven pediatric patients.

\section{Presentation of cases}

We collected the clinical and laboratory data of pediatric patients admitted to Prince Mohamed Bin Abdulaziz Hospital (PMAH), Ministry of Health, Riyadh, KSA. Nasopharyngeal swabs (NPSs) were tested for MERS$\mathrm{CoV}$ by using real-time reverse-transcriptase polymerase chain reaction (RT-PCR) as described previously $[4,23,24]$. The PCR test amplifies the upstream E protein (upE gene) and ORF1a of MERS-CoV. A positive test was considered when both assays were positive, and the samples were considered negative when the MERS-CoV RT-PCR was negative [4].

From April 2014 to November 2016, 295 patients of definite MERS were admitted to PMAH. Of these patients, seven $(2.4 \%)$ were children ( $<18$ years) (Table 1$)$, and $57 \%$ were female aged between 8 months and 16 years. One patient had bronchial asthma and chronic renal disease, and another patient had sickle cell disease. The five other cases had no underlying illnesses.

Of the seven cases, four patients sought medical advice within 1-7 days from the onset of symptoms. The other three $(43 \%)$ patients were asymptomatic and were in contact with confirmed patients who acquired MERS-CoV.
The most common presenting symptoms were fever $(57 \%)$, cough (14\%), shortness of breath (14\%), diarrhea (28\%), and vomiting (28\%) (Fig. 1).

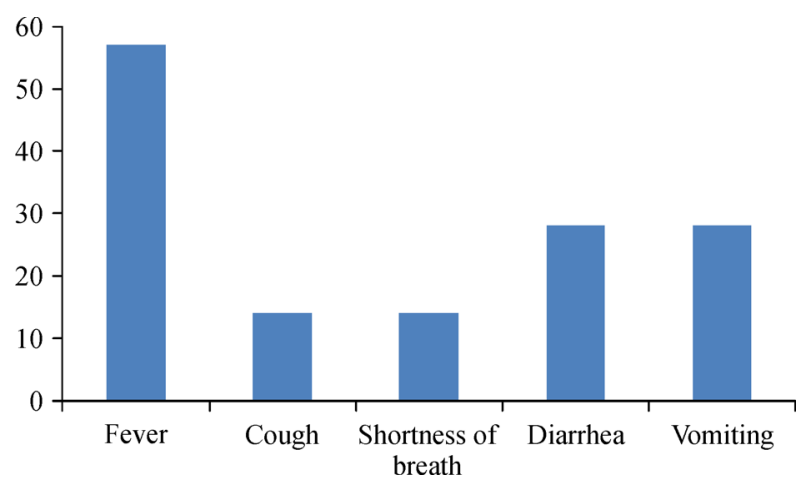

Fig. 1 Graph showing the most common clinical findings (percentage) among the presented pediatric MERS-CoV cases.

Of the seven cases, two (28.6\%) cases had platelet counts of $<150 \times 10^{9} / \mathrm{L}$, and one had an elevated creatinine level due to an underlying ESRD. The rest of the patients had normal blood count, liver function test, and urea and creatinine levels (Table 2). The documented MERS-CoV Ct values were $32-38$ for four of the seven cases.

Two (28.6\%) patients had abnormal chest radiographic findings of bilateral infiltration (Fig. 2). One (14.3\%) required ventilatory support, and two $(28.6 \%)$ required supplemental oxygen. All the seven patients were discharged without complications.

Table 1 Summary of clinical presentation and outcome of pediatric MERS-CoV cases

\begin{tabular}{|c|c|c|c|c|c|c|c|c|c|}
\hline Number & $\begin{array}{l}\text { Age } \\
\text { (years) }\end{array}$ & Gender & Symptom & Comorbidity & CXR finding & $\begin{array}{l}\text { Intensive care } \\
\text { unit }\end{array}$ & $\begin{array}{l}\text { Days of illness } \\
\text { before } \\
\text { hospitalization }\end{array}$ & Linked to & $\mathrm{O}_{2}$ requirement \\
\hline$\overline{1}$ & 16 & Male & $\begin{array}{l}\text { Fever, SOB, } \\
\text { diarrhea, } \\
\text { vomiting }\end{array}$ & ESRD, asthma & $\begin{array}{r}\text { Pneumonic } \\
\text { infiltration }\end{array}$ & YES & 2 & $\begin{array}{l}\text { Contact with } \\
\text { confirmed case }\end{array}$ & 6 days \\
\hline 2 & 10 & Female & $\begin{array}{l}\text { Fever, cough, } \\
\text { vomiting, } \\
\text { diarrhea }\end{array}$ & NO & Normal & $\mathrm{NO}$ & 7 & NA & Nil \\
\hline 3 & 13 & Female & Fever & Miliary TB & Bilateral diffuse & NO & 2 & NA & 12 days \\
\hline 4 & 6 & Female & Fever & NO & Normal & NO & 1 & No & Nil \\
\hline 5 & 0.75 & Male & Asymptomatic & NO & Normal & NO & Asymptomatic & $\begin{array}{l}\text { Mother and } \\
\text { grandmother } \\
\text { confirmed cases }\end{array}$ & Nil \\
\hline 6 & 9 & Female & Asymptomatic & Sickle cell anemia & Normal & NO & Asymptomatic & NA & Nil \\
\hline 7 & 1.5 & Male & Asymptomatic & NO & Normal & $\mathrm{NO}$ & Asymptomatic & $\begin{array}{l}\text { Mother } \\
\text { confirmed case }\end{array}$ & Nil \\
\hline
\end{tabular}


Table 2 Laboratory data on presentation of pediatric MERS-CoV cases

\begin{tabular}{llllllllllll}
\hline Number & Viral Ct value & WBC & Hgb & Plat & Neut count & Neut $\%$ & CK & ALT & AST & Creat & Albumin \\
\hline 1 & NA & 6.1 & 91 & 58 & 4.95 & 81.0 & 169 & 37 & 91 & 1256.1 & NA \\
2 & 37 & 3.8 & 149 & 145 & 0.18 & 4.6 & NA & NA & NA & NA & 34 \\
3 & 32 & 3 & 90 & 467 & 2.25 & 70.6 & NA & 6 & 71 & 44 & 26 \\
4 & 36 & 8.6 & 138 & 500 & 5.14 & 60.0 & NA & NA & NA & NA & 41 \\
5 & NA & 17.9 & 105 & 406 & 1.93 & 10.8 & 62 & NA & NA & 36.3 & NA \\
6 & 38 & 13.3 & 77 & 352 & 9.19 & 69.2 & NA & NA & NA & NA & 44 \\
7 & NA & 11 & 113 & 383 & 2.16 & 19.6 & NA & 23 & 42 & NA & 45 \\
\hline
\end{tabular}

WBC, white blood cell; Hgb, hemoglobin; Plat, platelet; Neut, neutrophil; CK, creatinine kinase; ALT, alanine aminotransferase; AST, aspartate aminotransferase; Creat, creatinine; NA, not available.

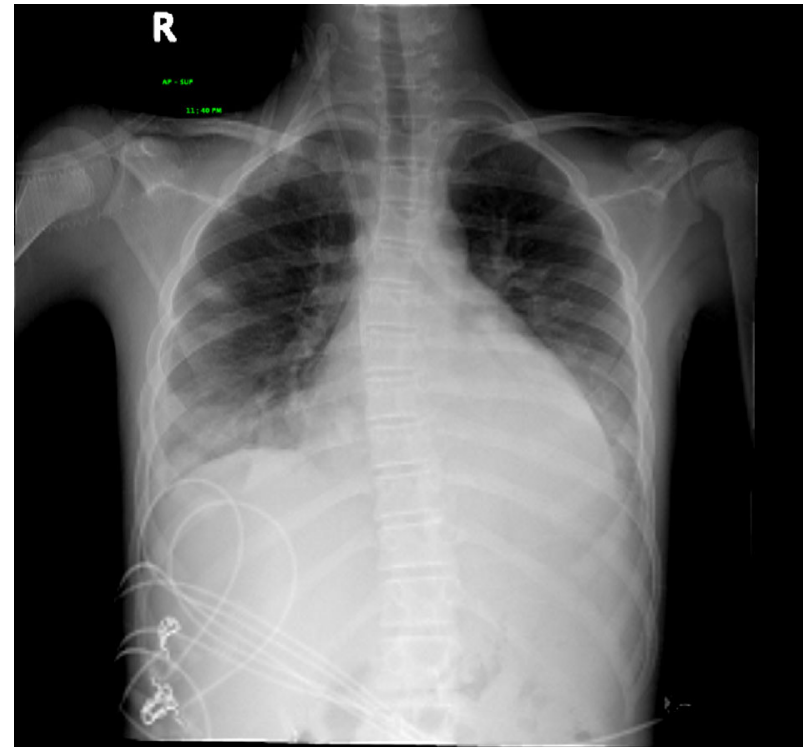

Fig. 2 Portable chest X-ray showing bilateral mid and lower zone patchy air space consolidation with mild right-sided pleural effusion. $\mathrm{R}$, right side.

\section{Discussion}

One characteristic feature of MERS-CoV is the extremely low number of children who were affected by the disease. In this report, we found a low rate of pediatric MERS-CoV infection and constituted only $2.4 \%$ of all admitted patients to this MERS-CoV referral hospital. The prevalence of MERS-CoV among children and adults was evaluated in two large studies. In a contact screening of 616 children, only nine $(1.9 \%)$ children were positive compared with $2.2 \%$ among 4440 adults ( $>17$ years of age) [25]. In a second study, children $(<14$ years of age) had positive MERS-CoV by PCR test in 10 of $8032(0.1 \%)$ compared with 372 of $48386(0.7 \%)$ [21]. In adults, the pattern of MERS infection could be sporadic cases, health-careassociated infection or transmission within families [26].
In contrast to infection in adults where health-careassociated infection is predominant [26], most confirmed pediatric cases were related secondary to exposure to other MERS-CoV cases within the same family [17]. The female-to-male ratio in childhood MERS-CoV was 1:1.7 [17], which is not similar to the ratio obtained in this study. The clinical presentation of MERS in adults ranges from asymptomatic to fatal and severe cases [26-28]. By contrast, the course of pediatric MERS cases is usually mild or asymptomatic [17].

Considering that MERS-CoV is a respiratory disease, the most common symptoms in adults were respiratory in nature [26]. In this small case series, fever was the predominant symptom (57\%), followed by vomiting $(28 \%)$, diarrhea (28\%), cough (14\%), and shortness of breath (14\%). Gastrointestinal symptoms were also common manifestations among adult patients [4,26,29].

Variable hematologic and hepatic panel findings were described among adult patients with MERS-CoV and indicated conditions, such as thrombocytopenia and thrombocytosis [30]. In this report, two (28.6\%) patients had thrombocytopenia, and the other patients had normal blood count and liver function test. Chronic renal disease was observed in only one patient in the current series, and renal dysfunction was a major pre-existing disease in adults [3]. In this report, all patients were discharged without complications. In the previous review of 31 pediatric cases, the fatality rate was $33.3 \%$ [17].

The occurrence of mild diseases in the pediatric age group has no clear explanation. Possible explanations for these findings include low exposure of pediatrics to MERS-CoV, presence of asymptomatic children and mildly symptomatic patients, or the existence of unidentified factors [17]. The manifestation of MERS as asymptomatic or mildly symptomatic may lead to under-detection due to low clinical suspicion. Whether any correlation exists between the occurrence of MERS in children and associated immunological factors is not known. In adults, serologic responses were not detected in asymptomatic infection but were $60 \%, 93.8 \%$, and $100 \%$ in symptomatic 
patients without pneumonia, pneumonia without respiratory failure, and with pneumonia and respiratory failure, respectively [31]. For adult patients with MERS-CoV, longer intensive care unit stays and more prolonged virus shedding were associated with $\mathrm{CD}^{+}{ }^{+} \mathrm{T}$-cell responses compared with those of children [32]. In animal model, the development of specific $\mathrm{CD}^{+} \mathrm{T}$ cell and virus-neutralizing antibodies may result in protection against MERS-CoV [33-36]. Thus, children may have a different immunologic response with less $\mathrm{CD}^{+}{ }^{+} \mathrm{T}$-cell responses, resulting in a lower rate of and less severe infection compared with adults. Further studies are needed to better understand pediatric MERS-CoV in terms of clinical presentation, infectivity, and outcome.

\section{Conclusions}

MERS-CoV remains an uncommon disease among children, and its course follows a milder path among children than those of adults. Majority of cases were asymptomatic and were diagnosed during the course of contact investigation.

\section{Compliance with ethics guidelines}

Sarah H. Alfaraj, Jaffar A. Al-Tawfiq, Talal A. Altuwaijri, and Ziad A. Memish declare no conflict of interest. Ethical board approval is not applicable in this case series. All procedures followed were in accordance with the ethical standards of the responsible committee on human experimentation (institutional and national) and with the Helsinki Declaration of 1975, as revised in 2000 (5).

\section{References}

1. Zaki AM, van Boheemen S, Bestebroer TM, Osterhaus ADME, Fouchier RAM. Isolation of a novel coronavirus from a man with pneumonia in Saudi Arabia. N Engl J Med 2012; 367(19): 18141820

2. Al-Tawfiq JA, Memish ZA. Middle East respiratory syndrome coronavirus: epidemiology and disease control measures. Infect Drug Resist 2014; 7: 281-287

3. Assiri A, McGeer A, Perl TM, Price CS, Al Rabeeah AA, Cummings DAT, Alabdullatif ZN, Assad M, Almulhim A, Makhdoom H, Madani H, Alhakeem R, Al-Tawfiq JA, Cotten M, Watson SJ, Kellam P, Zumla AI, Memish ZA; KSA MERS-CoV Investigation Team. Hospital outbreak of Middle East respiratory syndrome coronavirus. N Engl J Med 2013; 369(5): 407-416

4. Assiri A, Al-Tawfiq JA, Al-Rabeeah AA, Al-Rabiah FA, Al-Hajjar S, Al-Barrak A, Flemban H, Al-Nassir WN, Balkhy HH, AlHakeem RF, Makhdoom HQ, Zumla AI, Memish ZA. Epidemiological, demographic, and clinical characteristics of 47 cases of Middle East respiratory syndrome coronavirus disease from Saudi Arabia: a descriptive study. Lancet Infect Dis 2013; 13(9): 752-761
5. Penttinen PM, Kaasik-Aaslav K, Friaux A, Donachie A, Sudre B, Amato-Gauci AJ, Memish ZA, Coulombier D. Taking stock of the first 133 MERS coronavirus cases globally - is the epidemic changing? Euro Surveill 2013; 18(39): 20596

6. World Health Organization (WHO). Middle East respiratory syndrome coronavirus (MERS-CoV). WHO, 2017

7. Oboho IK, Tomczyk SM, Al-Asmari AM, Banjar AA, Al-Mugti H, Aloraini MS, Alkhaldi KZ, Almohammadi EL, Alraddadi BM, Gerber SI, Swerdlow DL, Watson JT, Madani TA. 2014 MERSCoV outbreak in Jeddah - a link to health care facilities. N Engl J Med 2015; 372(9): 846-854

8. Drosten C, Muth D, Corman VM, Hussain R, Al Masri M, HajOmar W, Landt O, Assiri A, Eckerle I, Al Shangiti A, Al-Tawfiq JA, Albarrak A, Zumla A, Rambaut A, Memish ZA. An observational, laboratory-based study of outbreaks of Middle East respiratory syndrome coronavirus in Jeddah and Riyadh, kingdom of Saudi Arabia, 2014. Clin Infect Dis 2015; 60(3): 369-377

9. Al-Tawfiq JA, Memish ZA. An update on Middle East respiratory syndrome: 2 years later. Expert Rev Respir Med 2015; 9(3): 327335

10. Al-Tawfiq JA, Memish ZA. Middle East respiratory syndrome coronavirus: transmission and phylogenetic evolution. Trends Microbiol 2014; 22(10): 573-579

11. Hijawi B, Abdallat M, Sayaydeh A, Alqasrawi S, Haddadin A, Jaarour N, Alsheikh S, Alsanouri T. Novel coronavirus infections in Jordan, April 2012: epidemiological findings from a retrospective investigation. East Mediterr Health J 2013; 19(Suppl 1): S12-S18

12. Kim Y, Lee S, Chu C, Choe S, Hong S, Shin Y. The characteristics of Middle Eastern respiratory syndrome coronavirus transmission dynamics in South Korea. Osong Public Health Res Perspect 2016; 7(1): 49-55

13. Seong MW, Kim SY, Corman VM, Kim TS, Cho SI, Kim MJ, Lee SJ, Lee JS, Seo SH, Ahn JS, Yu BS, Park N, Oh MD, Park WB, Lee JY, Kim G, Joh JS, Jeong I, Kim EC, Drosten C, Park SS. Microevolution of outbreak-associated Middle East respiratory syndrome coronavirus, South Korea, 2015. Emerg Infect Dis 2016; 22(2): 327-330

14. Memish ZA, Cotten M, Watson SJ, Kellam P, Zumla A, Alhakeem RF, Assiri A, Rabeeah AA, Al-Tawfiq JA. Community case clusters of Middle East respiratory syndrome coronavirus in Hafr Al-Batin, Kingdom of Saudi Arabia: a descriptive genomic study. Int J Infect Dis 2014; 23: 63-68

15. Memish ZA, Al-Tawfiq JA, Assiri A, AlRabiah FA, Al Hajjar S, Albarrak A, Flemban H, Alhakeem RF, Makhdoom HQ, Alsubaie S, Al-Rabeeah AA. Middle East respiratory syndrome coronavirus disease in children. Pediatr Infect Dis J 2014; 33(9): 904-906

16. WHO. MERS-CoV summary and literature update - as of 20 June 2013. 2013. http://www.who.int/csr/disease/coronavirus_infections/ update_20130620/en/

17. Al-Tawfiq JA, Kattan RF, Memish ZA. Middle East respiratory syndrome coronavirus disease is rare in children: an update from Saudi Arabia. World J Clin Pediatr 2016; 5(4): 391-396

18. Fagbo SF, Garbati MA, Hasan R, AlShahrani D, Al-Shehri M, AlFawaz T, Hakawi A, Wani TA, Skakni L. Acute viral respiratory infections among children in MERS-endemic Riyadh, Saudi Arabia, 2012-2013. J Med Virol 2017; 89(2): 195-201

19. Alhamlan FS, Majumder MS, Brownstein JS, Hawkins J, Al-Abdely 
HM, Alzahrani A, Obaid DA, Al-Ahdal MN, BinSaeed A. Case characteristics among Middle East respiratory syndrome coronavirus outbreak and non-outbreak cases in Saudi Arabia from 2012 to 2015. BMJ Open 2017; 7(1): e011865

20. Aleanizy FS, Mohmed N, Alqahtani FY, El Hadi Mohamed RA. Outbreak of Middle East respiratory syndrome coronavirus in Saudi Arabia: a retrospective study. BMC Infect Dis 2017; 17(1): 23

21. Saeed AA, Abedi GR, Alzahrani AG, Salameh I, Abdirizak F, Alhakeem R, Algarni H, El Nil OA, Mohammed M, Assiri AM, Alabdely HM, Watson JT, Gerber SI. Surveillance and testing for Middle East respiratory syndrome coronavirus, Saudi Arabia, April 2015-February 2016. Emerg Infect Dis 2017; 23(4): 682-685

22. Command and Control Center Ministry of Health Kingdom of Saudi Arabia Scientific Advisory Board. Infection Prevention and Control Guidelines for Middle East Respiratory Syndrome Coronavirus (MERS-CoV) Infection 2015. http://www.moh.gov.sa/en/CCC/StaffRegulations/Corona/Documents/IPC Guidelines for MERS-coV Infection.pdf (accessed March 9, 2017)

23. Al-Tawfiq JA, Hinedi K, Ghandour J, Khairalla H, Musleh S, Ujayli A, Memish ZA. Middle East respiratory syndrome coronavirus: a case-control study of hospitalized patients. Clin Infect Dis 2014; 59 (2): 160-165

24. Corman VM, Müller MA, Costabel U, Timm J, Binger T, Meyer B, Kreher P, Lattwein E, Eschbach-Bludau M, Nitsche A, Bleicker T, Landt O, Schweiger B, Drexler JF, Osterhaus AD, Haagmans BL, Dittmer U, Bonin F, Wolff T, Drosten C. Assays for laboratory confirmation of novel human coronavirus (hCoV-EMC) infections. Euro Surveill 2012; 17(49): 49

25. Memish ZA, Al-Tawfiq JA, Makhdoom HQ, Al-Rabeeah AA, Assiri A, Alhakeem RF, AlRabiah FA, Al Hajjar S, Albarrak A, Flemban H, Balkhy H, Barry M, Alhassan S, Alsubaie S, Zumla A. Screening for Middle East respiratory syndrome coronavirus infection in hospital patients and their healthcare worker and family contacts: a prospective descriptive study. Clin Microbiol Infect 2014; 20(5): 469-474

26. Al-Tawfiq JA, Memish ZA. Managing MERS-CoV in the healthcare setting. Hosp Pract (1995) 2015; 43(3): 158-163

27. Al-Tawfiq JA, Memish ZA. Update on therapeutic options for Middle East respiratory syndrome coronavirus (MERS-CoV). Expert Rev Anti Infect Ther 2017; 15(3):269-275

28. Al-Tawfiq JA, Omrani AS, Memish ZA. Middle East respiratory syndrome coronavirus: current situation and travel-associated concerns. Front Med 2016; 10(2): 111-119

29. Mohd HA, Memish ZA, Alfaraj SH, McClish D, Altuwaijri T, Alanazi MS, Aloqiel SA, Alenzi AM, Bafaqeeh F, Mohamed AM, Aldosari K, Ghazal S. Predictors of MERS-CoV infection: a large case control study of patients presenting with ILI at a MERS-CoV referral hospital in Saudi Arabia. Travel Med Infect Dis 2016; 14(5): 464-470

30. Al-Tawfiq JA, Hinedi K, Abbasi S, Babiker M, Sunji A, Eltigani M. Hematologic, hepatic, and renal function changes in hospitalized patients with Middle East respiratory syndrome coronavirus. Int J Lab Hematol 2017; 39(3): 272-278

31. Ko JH, Müller MA, Seok H, Park GE, Lee JY, Cho SY, Ha YE, Baek JY, Kim SH, Kang JM, Kim YJ, Jo IJ, Chung CR, Hahn MJ, Drosten C, Kang CI, Chung DR, Song JH, Kang ES, Peck KR. Serologic responses of 42 MERS-coronavirus-infected patients according to the disease severity. Diagn Microbiol Infect Dis 2017; 89(2): 106-111

32. Zhao J, Alshukairi AN, Baharoon SA, Ahmed WA, Bokhari AA, Nehdi AM, Layqah LA, Alghamdi MG, Al Gethamy MM, Dada AM, Khalid I, Boujelal M, Al Johani SM, Vogel L, Subbarao K, Mangalam A, Wu C, Ten Eyck P, Perlman S, Zhao J. Recovery from the Middle East respiratory syndrome is associated with antibody and T-cell responses. Sci Immunol 2017; 2(14): eaan5393

33. Volz A, Kupke A, Song F, Jany S, Fux R, Shams-Eldin H, Schmidt J, Becker C, Eickmann M, Becker S, Sutter G. Protective efficacy of recombinant modified vaccinia virus Ankara delivering Middle East respiratory syndrome coronavirus spike glycoprotein. J Virol 2015; 89(16): 8651-8656

34. Lan J, Deng Y, Chen H, Lu G, Wang W, Guo X, Lu Z, Gao GF, Tan $\mathrm{W}$. Tailoring subunit vaccine immunity with adjuvant combinations and delivery routes using the Middle East respiratory coronavirus (MERS-CoV) receptor-binding domain as an antigen. PLoS One 2014; 9(11): e112602

35. Liu WJ, Zhao M, Liu K, Xu K, Wong G, Tan W, Gao GF. T-cell immunity of SARS-CoV: implications for vaccine development against MERS-CoV. Antiviral Res 2017; 137: 82-92

36. Liu WJ, Lan J, Liu K, Deng Y, Yao Y, Wu S, Chen H, Bao L, Zhang H, Zhao M, Wang Q, Han L, Chai Y, Qi J, Zhao J, Meng S, Qin C, Gao GF, Tan W. Protective T cell responses featured by concordant recognition of Middle East respiratory syndrome coronavirusderived CD8 ${ }^{+}$T cell epitopes and host MHC. J Immunol 2017; 198 (2): $873-882$ 